Canadian

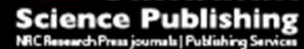

Canadian Journal of Chemistry Revue canadienne de chimie

\title{
Synthesis of the symmetrical methylene diesters from carboxylic ionic liquids
}

\begin{tabular}{|c|c|}
\hline Journal: & Canadian Journal of Chemistry \\
\hline Manuscript ID & cjc-2017-0042.R1 \\
\hline Manuscript Type: & Article \\
\hline Date Submitted by the Author: & 31-Mar-2017 \\
\hline Complete List of Authors: & $\begin{array}{l}\text { Gómora-Herrera, Diana; CIITEC-IPN } \\
\text { Lijanova, Irina; CIITEC-IPN, } \\
\text { Olivares-Xometl, Octavio; Benemérita Universidad Autónoma de Puebla, } \\
\text { Facultad de Ingeniería Química } \\
\text { Toscano, Alfredo; Instituto de Química-UNAM, Química Inorgánica } \\
\text { Likhanova, Natalya; Instituto Mexicano del Petroleo, Gerencia de Ingeniería } \\
\text { de Recuperación Adicional }\end{array}$ \\
\hline $\begin{array}{r}\text { Is the invited manuscript for } \\
\text { consideration in a Special } \\
\text { Issue?: }\end{array}$ & N/A \\
\hline Keyword: & $\begin{array}{l}\text { Ionic liquids, Dichloromethane, Methylene diesters, Crystal structure, } \\
\text { Hydrogen bonding }\end{array}$ \\
\hline
\end{tabular}

\section{SCHOLARONE}

Manuscripts 


\section{Synthesis of the symmetrical methylene diesters from carboxylic ionic liquids.}

2

3 a Instituto Politécnico Nacional, CIITEC, Cerrada Cecati S/N, Colonia Santa Catarina de Azcapotzalco, CP 02250,

4 México, D.F., México.

$5 \quad{ }^{b}$ Benemérita Universidad Autónoma de Puebla, Facultad de Ingeniería Química, Av. San Claudio y 18 Sur, Col.

6 San Manuel, Ciudad Universitaria, Puebla, 72570, México

7 ' Instituto de Química, Universidad Nacional Autónoma de México, Cd. Universitaria, Circuito Exterior, Coyoacán,

8 CP. 04510, México D.F., México

9 d Instituto Mexicano del Petróleo, Gerencia de Ingeniería de Recuperación Adicional, Eje Central Norte Lázaro

10 Cárdenas No. 152, Col. San Bartolo Atepehuacan, CP 07730, México, DF, México. Tel: 52 5591758382; e-mail:

11 nvictoro@imp.mx 


\section{ABSTRACT}

2 The reaction between carboxylic ionic liquids and dichloromethane, which provokes the

3 formation of symmetrical methylene diesters, was carried out. The synthesis of these ionic liquid

4 compounds was carried out in a microwave reactor and the characterization by spectroscopic

5 techniques of methylene diesters (methylene di-2-furoate, methylene di-2-picolinate, methylene

6 dianthranilate, and methylene dioleate) is described and the crystal structures discussed. The

7 crystal packing of methylene dianthranilate is characterized by trimer formation due to hydrogen

8 bonding via interactions between the hydrogen atom of the primary amine group and the oxygen

9 of the carboxylic group.

10 Keywords: Ionic liquids, methylene diesters, dichloromethane, crystal structure, hydrogen

11 bonding 
1

2

3

4

5

6 7 for obtaining acetic acid, and NOVARTIS ${ }^{6}$.

8 The previously mentioned applications have to do with well-acknowledged features that ILs

9 possess such as extremely strong polarization and solvation properties, nevertheless, the studies

\section{Introduction}

Nowadays, ionic liquids (ILs) are almost ubiquitous in many industrial processes such as BASIL $^{1}$, which produces coxyphenylphosphines; BASF $^{2}$, for the separation of azeotropic mixtures and alcohol chlorination; DIFASOL ${ }^{3}$, patented by the French Institute of Petroleum and used for the dimerization of alkenes; and DEGUSSA ${ }^{4}$, where the ILs are used as paint additives and as electrolytes in lithium batteries; in addition, there are processes such as EASTMANN ${ }^{5}$, on their chemical and thermal stabilities, among other characteristics, are still a current topic. The present work deals with the study of the reaction between the ILs and a carboxylate-type anion, using dichloromethane as a common solvent for the easy synthesis of methylene diesters (MDEs) with high yield rates.

The potential application of MDEs in the medicine branch has been described in the literature. Heffernan et al. have described the MDE application of a 4H-furo[3,2-b]pyrrole-5carboxylic acid as an oxidation inhibitor of D-amino acids, which allows the use of these compounds in Alzheimer treatments and as anticonvulsants ${ }^{7}$, where MDEs derived from valproic $\operatorname{acid}^{8}$ have also been reported regarding this purpose.

Researchers at the University of Toulouse synthesized symmetric and asymmetric MDEs, including the structure of an antimicrobial drug, levofloxacin, in the molecule, and evaluated them in-vitro as growth inhibitors of carcinogenic tumours 9 .

At Oxford and Cambridge Universities, researchers reported on the application of a MDE as an analogue compound of cyclic ADP-ribose ${ }^{10,11}$ whereas in Israel, the same structure was identified as part of a psychotropic agent and as a prodrug with anticarcinogenic effects ${ }^{12-16}$. In addition, methylene-dipropionate features anti-fungal properties and can be used for preserving organic materials ${ }^{17}$. 
There are several patents on the application of MDEs, derived either from acrylic or

2 methacrylic acids, in the preparation of polymers for different purposes such as hydrophobic 3 coatings in contact lenses ${ }^{18,19}$, preparation of magnetic spheres ${ }^{20}$, enhanced oil recovery (EOR) ${ }^{21}$, 4 dental resins ${ }^{22}$ and agents for the formation of images ${ }^{23,24}$. MDEs derived from fatty acids 5 (stearic and tricosanoic) have been reported as paint compounds for thermal transfer ${ }^{25}$.

According to the aforesaid, the search for new synthesis pathways for obtaining

7 compounds suitable for being the precursors of pharmaceutical drugs, among other purposes, is a 8 current task in the scientific field. In the present work, four MDEs were synthesized from 9 trialkylammonium carboxylates by means of a reaction with dichloromethane under mild conditions in microwave (MW) reactor: methylene di-2-furoate, methylene di-2-picolinate, methylene dianthranilate and methylene dioleate with a yield rate above $80 \%$.

\section{Materials and methods}

All the chemical compounds used for the syntheses and tests (except otherwise stated) had $>98 \%$ purity and were purchased from Sigma-Aldrich. All the synthesized compounds were characterized by ${ }^{1} \mathrm{H}$ and ${ }^{13} \mathrm{C}$ NMR, and infrared (IR) spectroscopy. IR spectra were recorded on a Thermoscientific Nicolet 8700 Spectrometer. ${ }^{1} \mathrm{H}(300 \mathrm{MHz})$ and ${ }^{13} \mathrm{C}$ NMR $(75.4 \mathrm{MHz})$ spectra were recorded on a JEOL Eclipse-300 equipment in $\mathrm{CDCl}_{3}$, and chemical shifts are expressed in ppm relative to tetramethylsilane as the internal standard. Three ILs (methyltriethylammonium 2-furoate, methyltriethylammonium anthranilate and methyltriethylammonium picolinate) were synthesized starting from methyltriethylammonium methylcarbonate as feedstock, while the (2hydroxyethyl)trimethylammonium oleate was synthesized starting from

22 hydroxyethyl)trimethylammonium bicarbonate.

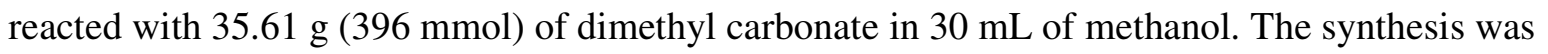
performed using a Parr reactor model 4848, designed for synthesis; the reactor was equipped 
1 with a stirrer as well as temperature controls, and the reaction mixture was kept at $150{ }^{\circ} \mathrm{C}$ under

2 stirring for $6 \mathrm{~h}$. Once the reaction was finished, the mixture was filtered, and the solution 3 evaporated with vacuum to remove both the residual dimethyl carbonate (b. p. $90.3{ }^{\circ} \mathrm{C}$ ) and 4 methanol (b. p. $\left.64.7^{\circ} \mathrm{C}\right)$. The crude compound was washed thrice with ethyl acetate $(3 \times 50 \mathrm{~mL})$.

5 Finally, the solvents were removed with vacuum. The $33.34 \mathrm{~g}$ of yellow viscous liquid were 6 obtained with a yield of $89 \%$. FTIR: 2987, 2619, 1462, 1643, 2987, 1462, 1369, 1196, 976, 837

$7 \quad \mathrm{~cm}^{-1} .{ }^{1} \mathrm{H} N M R\left(300 \mathrm{MHz}, \mathrm{CDCl}_{3}\right): \delta 1.37(t, J=7.14 \mathrm{~Hz}, 9 \mathrm{H}), 3.13(\mathrm{~s}, 3 \mathrm{H}), 3.35(\mathrm{~s}, 3 \mathrm{H}), 3.45-3-$ $853(\mathrm{~m}, 6 \mathrm{H}) \mathrm{ppm} .{ }^{13} \mathrm{CNMR}\left(75 \mathrm{MHz}_{\mathrm{C}} \mathrm{CDCl}_{3}\right): \delta 7.9,52.2,55.7,58.7,158.3 \mathrm{ppm}$. Methyltriethylammonium 2-furoate (2a): $2.93 \mathrm{~g}$ of 2-furoic acid (26 mmol) were dissolved in $25 \mathrm{~mL}$ of methanol, and $25 \mathrm{~mL}$ of methanol solution containing $5.00 \mathrm{~g}$ (26 mmol) of methyltriethylammonium methyl carbonate (1) were added to the mixture. The reaction occurred with the release of gas. The reaction was kept under constant stirring for $30 \mathrm{~min}$ at $40{ }^{\circ} \mathrm{C}$. After reaction completion, the solvents were removed by vacuum evaporation and the product was washed thrice with ethyl acetate $(3 \times 50 \mathrm{~mL})$. Finally, the synthesized ILs were dried under 152.7, 166.6 ppm. Methyltriethylammonium anthranilate $(\mathbf{2 b})$ : It was prepared by following the same procedure as the one described for methyltriethylammonium 2-furoate, but using $3.57 \mathrm{~g} \mathrm{(26}$ $\mathrm{mmol}$ ) of anthranilic acid instead of 2-furoic acid, obtaining $5.90 \mathrm{~g}$ of IL as a brown-yellowwaxy liquid with a yield of $90 \%$. FTIR: 3356, 3250, 2981, 1610,1530, 1363, 1310, 761, $658 \mathrm{~cm}^{-}$

$24 \quad{ }^{1} .{ }^{1} \mathrm{H} \mathrm{NMR}\left(300 \mathrm{MHz}, \mathrm{CD}_{3} \mathrm{OD}\right): \delta 1.12(t, \mathrm{~J}=2.00 \mathrm{~Hz}, 9 \mathrm{H}), 2.78(\mathrm{~s}, 3 \mathrm{H}), 3.10-3.15(\mathrm{~m}, 6 \mathrm{H}), 6.50$ $(t, J=6.84,1 H), 6.59(d, J=7.98,1 H), 7.00(t, J=6.87,1 H), 7.71\left(d d, J_{1}=7.71, J_{2}=1.65,1 H\right) p p m$. 
1

2 ppm.

3

${ }^{13} \mathrm{C} \mathrm{NMR}\left(75 \mathrm{MHz}, \mathrm{CD}_{3} \mathrm{OD}\right): \delta 8.1,57.1,60.3,117.0,117.7,121.5,132.3,132.9,151.0,176.0$

Methyltriethylammonium 2-picolinate $(2 \boldsymbol{c})$ : It was prepared by following the same procedure as the one described for methyltriethylammonium 2-furoate, but using $3.20 \mathrm{~g}$ (26 mmol) of 2-picolinic acid instead of 2-furoic acid, obtaining $5.45 \mathrm{~g}$ of IL as a brown semisolid with a yield of $88 \%$. FTIR: 3045, 2998, 1610, 1563, 1394, 1047, 839, 744, $708 \mathrm{~cm}^{-1} .{ }^{1} \mathrm{H} \mathrm{NMR}$ (300 MHz, CD $3 \mathrm{OD}): \delta 1.15(t, J=1.98 \mathrm{~Hz}, 9 H), 2.80(\mathrm{~s}, 3 \mathrm{H}), 3.15-3.24(\mathrm{~m}, 6 \mathrm{H}), 7.29-7.28(\mathrm{~m}$, $1 H), 7.72(t, J=6.80,1 H), 7.86(d, J=7.681 H), 8.44(d, J=4.11,1 H) p p m .{ }^{13} C \mathrm{NMR}(75 \mathrm{MHz}$, $\left.C D_{3} \mathrm{OD}\right): \delta 8.1,57.0,60.2,124.9,126.0,138.2,149.6,156.9,172.8 \mathrm{ppm}$.

(2-Hydroxyethyl)trimethylammonium oleate (3): $2.90 \mathrm{~g}$ of oleic acid (10.27 $\mathrm{mmol})$ were mixed with $2.29 \mathrm{~g}$ of choline bicarbonate $(13.86 \mathrm{mmol})$ in $25 \mathrm{~mL}$ of ethanol. The reaction occurred at room temperature under constant stirring for $4 \mathrm{~h}$. The solvent was removed by vacuum evaporation and the product was washed thrice with ethyl acetate $(3 \times 50 \mathrm{~mL})$. Finally, a drying process took place under vacuum at $90{ }^{\circ} \mathrm{C}$ for $6 \mathrm{~h}$. A yellowish liquid was obtained with a yield of $95 \%(3.63 \mathrm{~g}) . \operatorname{FTIR}\left(\mathrm{cm}^{-1}\right): 3255,3020,2921,2850,1566,1466,1421,1097,949,871$, 723. ${ }^{1} \mathrm{H}$ NMR (301 MHz, acetone-d $) \delta 4.67(\mathrm{~m}, 2 \mathrm{H}), 3.40(\mathrm{~m}, 2 \mathrm{H}), 3.10(\mathrm{~s}, 9 H), 2.85(\mathrm{~m}, 6 \mathrm{H})$, $2.66(\mathrm{~s}, 1 \mathrm{H}), 1.41(\mathrm{~m}, 20 \mathrm{H}), 0.60(\mathrm{~d}, 2 \mathrm{H}), 0.45(\mathrm{t}, 3 \mathrm{H}), 0.20(\mathrm{t}, 3 \mathrm{H}) .{ }^{13} \mathrm{C} \mathrm{NMR}(76 \mathrm{MHz}$, Acetone$\left.d_{6}\right) \delta(\mathrm{ppm}): 180.71,130.67,130.39,68.66,57.63,56.62,54.66,38.98,32.53,27.86,27.70$, $27.41,23.25,18.61,14.35$.

Methylene di-2-furoate (4a): methyltriethylammonium 2-furoate (2a) (0.455 g, 2 mmol) was dissolved in dichloromethane $(5 \mathrm{~mL})$. The solution was poured into a tube of the Microwave 300 Synthesis Reactor from Anton Paar, designed for synthesis and equipped with a stirrer as well as temperature controls. The reaction mixture was kept at $130{ }^{\circ} \mathrm{C}$ under stirring at $600 \mathrm{rpm}$, pressure of 12.1 bar, power of $15 \mathrm{~W}$ for $10 \mathrm{~min}$. Once the reaction was finished, dichloromethane was removed under vacuum. The product was dissolved in $20 \mathrm{~mL}$ of hot ethanol and filtered over charcoal. The resulting solution was then placed in a freezer $(263 \mathrm{~K})$ for 
$124 \mathrm{~h}$; after this time, crystals of the compound were harvested. White crystals were obtained with 2 a yield of $87 \%\left(0.20\right.$ g). M.p. 119-121 ${ }^{\circ}$ C. FTIR: 3143, 2999, 2347, 1724, 1472, 1285, 1171, $3 \quad 1057,968,785 \mathrm{~cm}^{-1} .{ }^{1} \mathrm{H} \operatorname{NMR}\left(300 \mathrm{MHz}, \mathrm{CDCl}_{3}\right): \delta 6.16(\mathrm{~s}, 2 \mathrm{H}), 6.53-6.55(\mathrm{~m}, 2 \mathrm{H}), 7.29-7.30$ $4 \quad(\mathrm{~m}, 2 \mathrm{H}), 7.63-7.64(\mathrm{~m}, 2 \mathrm{H}) \mathrm{ppm} .{ }^{13} \mathrm{C} \mathrm{NMR}\left(75 \mathrm{MHz}, \mathrm{CDCl}_{3}\right): \delta 79.3,112.2,119.8,143.4,147.4$, $5 \quad 157.0 \mathrm{ppm}$. Methylene dianthranilate (4b): methyltriethylammonium anthranilate (2b) (0.51 g, 2

mmol) was dissolved in dichloromethane $(5 \mathrm{~mL})$. The solution was poured into a tube of a Microwave 300 Synthesis reactor from Anton Paar. The reaction mixture was kept at $130{ }^{\circ} \mathrm{C}$ under stirring at $600 \mathrm{rpm}$, pressure of $12.1 \mathrm{bar}$, and power of $15 \mathrm{~W}$ for $10 \mathrm{~min}$; then dichloromethane was removed under vacuum. The product was dissolved in $20 \mathrm{~mL}$ of hot ethanol and filtered over charcoal. The resulting solution was then placed in a freezer $(263 \mathrm{~K})$ for $24 \mathrm{~h}$; after this time, yellow crystals of the compound were harvested with a yield of $83 \%(0.24$ g). M.p. 103-105 ${ }^{\circ}$ C. FTIR: 3489, 3375, 2977, 2377, 1717, 1613, 1596, 1490, 1297, 1235, 1156, 1037, 995, $743 \mathrm{~cm}^{-1} .{ }^{1} H$ NMR (300 MHz, DMSO-d $): \delta 6.12(s, 2 H), 6.53(t, J=7.14,2 H), 6.69$ $(s, 4 H), 6.80(d, J=8.25,2 H), 7.25(t, J=7.17,2 H), 7.74(d, J=8.25,2 H) p p m .{ }^{13} C$ NMR (75 $\left.M H z, D M S O-d_{6}\right): \delta 79.3,107.5,115.0,116.7,130.7,134.8,152.0,166.0$ ppm.

Methylene di-2-picolinate (4c): methyltriethylammonium 2-picolinate (2c) (0.48 g, 2 mmol) was dissolved in $5 \mathrm{~mL}$ of dichloromethane. The reaction mixture was kept at $130{ }^{\circ} \mathrm{C}$ in Microwave Synthesis reactor under stirring at $600 \mathrm{rpm}$, pressure of $12.1 \mathrm{bar}$, and power of $15 \mathrm{~W}$ for $10 \mathrm{~min}$; then dichloromethane was removed under vacuum. The product was dissolved in 20 $\mathrm{mL}$ of hot ethanol and filtered over charcoal. The resulting solution was then placed in a freezer $(263 \mathrm{~K})$ for $24 \mathrm{~h}$; obtaining a yellow solid with a yield of $81 \%(0.21 \mathrm{~g})$. M.p. $74-76^{\circ} \mathrm{C}$. FTIR: $3437,3111,3081,2923,2854,2152,1737,1613,1453,1282,1161,1067,986,746,699,682$ $\mathrm{cm}^{-1} .{ }^{1} \mathrm{H} N M R\left(300 \mathrm{MHz}, \mathrm{CDCl}_{3}\right): \delta 6.40(\mathrm{~s}, 2 \mathrm{H}), 7.51-7.53(\mathrm{~m}, 2 \mathrm{H})$, 7.85-7.90 $(\mathrm{m}, 2 \mathrm{H}), 8.20(\mathrm{~d}$, $J=7.98,2 H), 8.80(d, J=4.11,2 H) p p m .{ }^{13} C N M R\left(75 M H z, C D C l_{3}\right): \delta 81.4,125.8,127.5,137.2$, 146.8, 150.1, 163.6 ppm. 
$2 \mathrm{mmol})$ was dissolved in dichloromethane $(6 \mathrm{~mL})$. The reaction mixture was kept at $130{ }^{\circ} \mathrm{C}$ in

3 MW reactor under stirring $600 \mathrm{rpm}$, pressure of $12.1 \mathrm{bar}$, and power of $15 \mathrm{~W}$ for $20 \mathrm{~min}$; then

4 dichlorometane was removed under vacuum. The product was dissolved in $20 \mathrm{~mL}$ of hexane and

5 then placed in a freezer $(263 \mathrm{~K})$ for $24 \mathrm{~h}$. The precipitate was filtered and discarded, while the

6 hexane solution was evaporated, obtaining a yellow waxy compound with a yield of $80 \%(0.32$

$7 \mathrm{~g}) . \operatorname{FTIR}\left(\mathrm{cm}^{-1}\right): 2921,2850,1660,1566,1466,1421 .{ }^{1} \mathrm{H} \mathrm{NMR}\left(300 \mathrm{MHz}, \mathrm{CDCl}_{3}\right): \delta 5.74(d$,

$8 J=12.8 \mathrm{~Hz}, 2 H), 5.33(\mathrm{~m}, 4 H), 2.19(t, 4 H), 2.0(d, J=5.6 \mathrm{~Hz}, 8 H), 1.56(m, 4 H), 1.28(d, J=10.3$

$9 \mathrm{~Hz}, 44 \mathrm{H}), 0.88(\mathrm{t}, \mathrm{J}=6.6 \mathrm{~Hz}, 6 \mathrm{H}) \mathrm{ppm} .{ }^{13} \mathrm{C} \mathrm{NMR}\left(75 \mathrm{MHz}, \mathrm{CDCl}_{3}\right): \delta$ 172.4, 129.7, 78.9, 31.9,

$10 \quad 29.3,27.2,22.7,14.1 \mathrm{ppm}$.

\section{Results and discussion}

The synthesis methods of the symmetric MDEs can be divided into three groups: 1) the most widely employed is by using methylene chloride derivatives obtained from the corresponding carboxylic acids with thionyl choride ${ }^{26,7,27}$; also methylene iodides ${ }^{28}$ or methylene fluorides $^{29}$ can be used instead of carboxylic acid methylene chlorides.; 2) by the oxidation method and, finally, 3) by using carboxylic acid salts and methane dihalides with phase transfer catalysts.

Formaldehyde or paraformaldehyde can be used in the synthesis of MDEs to form a methylene bridge between the two fragments of carboxylic acids; in this sense, even anhydrides

21 of carboxylic acids ${ }^{17,30}$ can be used instead of carboxylic acid methylene halides; the disadvantages of this method are that the reaction times are above $18 \mathrm{~h}$ at $100{ }^{\circ} \mathrm{C}$ and the use of a Grignard reagent is needed. 
An original synthesis method of MDEs through the oxidation of alcohols or ammines

2 with benzyltriethylammonium permanganate ${ }^{31}$, however, the formed reaction product is a 3 mixture of MDEs (62\%), chloromethane of the corresponding alcohol (11\%) and non-reacted 4 raw material (18\%), which implies low final MDE yields.

Another MDE synthesis method is based on the use of methane dihalides and on sodium,

6 potassium or cesium salts from the corresponding carboxylic acids ${ }^{32}$. Despite the implementation

7 of available and economic raw materials, this method features the disadvantage of performing

8 the reaction under phase transfer catalytic conditions, which implies the use of catalysts such as

9 polyethylene glycol $600^{33}, 18$-crown-6-ether ${ }^{34}$, ionic exchange resins of the Amberlite IRA- $400^{35}$

10 type, and hexamethylphosphoramide ${ }^{36}$.

11 The preparation method of a symmetrical MDE by mixing benzoic acid, a quaternary 12 amine salt (tetrabutylammonium sulfate) as catalyst and sodium hydroxide under reflux 13 conditions in dichloromethane for 4 days $^{37}$ lacks of good yields and the reaction times are too long. Notwithstanding, each one of these methods has serious disadvantages such as the use of expensive catalysts, low product yields or long reaction times ${ }^{38}$. In our previous work, we reported the synthesis of symmetrical methylene dibenzoic esters with a yield of $80 \%$ using trioctylammonium benzoate, obtained from Aliquat $336^{\mathrm{TM}}$, and silver benzoate ${ }^{39}$.

In this work, we present a new synthesis pathway of symmetrical MDEs from carboxylic ILs obtained from the corresponding methyl carbonate or carbonate ILs using MW energy. The carboxylic ILs were obtained in two stages: the synthesis of methyltriethylammonium methyl

21 carbonate using dimethyl carbonate (DMC) with triethylamine ${ }^{40}$; in the case of methyltriethylammonium 2-furoate (2a), methyltriethylammonium anthranilate $(2 b)$ and methyltriethylammonium 2-picolinate $(2 c)$ were interchanged by a carboxylic acid as show in

24 Figure 1; in the case of (2-hydroxyethyl)trimethylammonium oleate (3), we started from choline 
1 bicarbonate and oleic acid as show in Figure 2. It is noteworthy that the carbonate anion was

2 derived from a soft acid, which enabled the easy exchange by any desired anion.

5 The esterification reactions have been extensively explored with the use of $\mathrm{MWs}^{41}$. The

6 carboxylic ILs interacted as anions with dichloromethane forming MDEs (Figure 3), where the

7 MWs greatly accelerated the course of this reaction by generating charged leaving groups,

8 reducing the reaction time drastically and the use of catalysts was avoided, forming the

Figure 1. Synthesis scheme of methyltriethylammonium ILs (2a-c).

Figure 2. Synthesis scheme of (2-hydroxyethyl)trimethylammonium oleate (3). corresponding MDEs with good yield rates (Table1). In most cases, the reaction times were decreased up to 10 minutes, which shows not only the occurrence of purely thermal effects of the MWs, but also the probable effect of MWs on the position of the transition state along the reaction coordinate axis.

This pathway allows the synthesis of MDEs derived from substituted aromatic carboxylic acids, heterocyclic and alkylic acids, which stems from its versatile features and short reaction times, which even enable the researcher to obtain MDEs with bulky groups.

Figure 3. Synthesis scheme of symmetrical MDEs.

Table 1. Synthesized compounds.

By analyzing the spectra of the obtained MDEs, it can be said that the corresponding preparation method, using ILs as precursors, enables the synthesis of these compounds not only with good yield rates, but also with the right purity. As it can be observed in the NMR spectra of the MDEs, three 1.1-3.5 ppm signals disappeared for proton and 8.1-60.2 ppm for ${ }^{13} \mathrm{C}$ from the cationic branch of the ILs and a ${ }^{13} \mathrm{C}$ signal at $157-176 \mathrm{ppm}$ corresponding to the carboxylic group. On the 
1 other hand, new signals at 6.12-6.40 ppm for proton and at 79.3 and $81.4 \mathrm{ppm}$ for ${ }^{13} \mathrm{C}$, which

2 belong to the methylene bridge, can be seen, and another ${ }^{13} \mathrm{C}$ signal at $157-166 \mathrm{ppm}$ corresponds

3 to the ester carbonyl. The same trend prevails in the FTIR spectra, where new characteristic

4 bands of aromatic esters appear at $1717-1737 \mathrm{~cm}^{-1}$ and $1235-1285 \mathrm{~cm}^{-1}$, and the bands of the

5 carboxylic acid groups at $1610 \mathrm{~cm}^{-1}$ disappeared.

6 The structures of the MDEs were confirmed by X-ray analysis (Figures 4-7), however, MD-

7 oleate and MD-2-picolinate did not form the crystalline compounds, so it was impossible to

8 confirm their structure by this technique. Crystal data, data collection and structure refinement

9 details, where carbon atoms were treated as riding: $\mathrm{C}-\mathrm{C}=0.0019 \AA$ for methylene di-2-furoate

10 and $\mathrm{C}-\mathrm{C}=0.0115 \AA$ for methylene dianthranilate are summarized in Table 2.

Figure 4. Molecular structure of MDF with atom labels.

Figure 5. Molecular structure of MDA with atom labels.

Figure 6. Crystal packing of MDF.

Figure 7. Crystal packing of MDA.

Table 2. Experimental X-ray details.

The X-ray data indicate that these compounds have symmetrical crystal structures, where MDF crystallized in the monoclinic form, while MDA occurred in the trigonal form (Tables S1-S4). The 5- and 6-member rings remain planar, and carboxyl groups are located in the plane of the corresponding ring, while the methylene group is slightly rotated with respect to the furanoic or anthranilic rings. Selected geometric parameters are summarized in Tables S5-S6.

It is pertinent to note that the geometry of the cycles did not change during the formation of the MDEs, so the $\mathrm{C}_{2}-\mathrm{C}_{1}-\mathrm{C}_{6}$ angle is $119.7^{\circ}$, just like the $\mathrm{N}_{1}-\mathrm{C}_{2}-\mathrm{C}_{1}\left(122.5^{\circ}\right)$ and $\mathrm{N}_{1}-\mathrm{C}_{2}-\mathrm{C}_{3}$ angles $\left(119.7^{\circ}\right)$ are equal to the corresponding angles of the antharanilic acid, while the angles corresponding to $\mathrm{C}_{1}-\mathrm{C}_{7}-\mathrm{O}_{2}, \mathrm{C}_{1}-\mathrm{C}_{7}-\mathrm{O}_{1}$, and $\mathrm{C}_{8}-\mathrm{C}_{14}-\mathrm{O}_{3}$ and distances between $\mathrm{C}$ and $\mathrm{O}$ atoms $\left(\mathrm{C}_{7-}\right.$ 
$\left.1 \mathrm{O}_{1}, \mathrm{C}_{7}-\mathrm{O}_{2}, \mathrm{C}_{14}-\mathrm{O}_{3}, \mathrm{C}_{14}-\mathrm{O}_{4}\right)$ slightly increased in comparison with the acid, making the ester group

2 occupy more space than the carboxylic group of the acid ${ }^{43}$. The same trend exists for MDF,

3 where the angles and distances in the ring are very similar to those of furan; so, in our case, the

$4 \mathrm{C}(3)-\mathrm{C}(4)$ distance is $1.427 \AA$ and the $\mathrm{C}(10)-\mathrm{O}(6)-\mathrm{C}(7)$ angle is $106.19^{\circ} ; 1.430$ and $106.6^{\circ}$,

5 respectively, have been reported in the literature ${ }^{44,45}$.

6 The distances of the $\mathrm{C}-\mathrm{O}$ bonds in the methylene group are $1.43 \AA$ for both cases and are in good 7 agreement with those reported for methylene dibenzoate ${ }^{39}$. The angles formed by the carbon 8 atom of the methylene group and the vicinal oxygen are equal to $116 \AA$ for MDF, which 9 coincides with methylene dibenzoate. However, for MDA, this distance is $115.2 \AA$; this slight 10 reduction of the angle can be explained by the hydrogen bond formed between compounds due 11 to interactions between the amine group $\mathrm{N}-\mathrm{H} \ldots \mathrm{O}-\mathrm{C}$ and oxygen of the carboxylic group of 12 MDA (Tables S7 and S8). In the crystal, the molecules are linked by the aforesaid interactions, 13 forming the crystal packing, where there are no other significant intermolecular interactions.

\section{Conclusions}

New symmetrical methylene diesters were obtained with good yields from the reaction between methylene chloride and the corresponding IL with a carboxylic anion under MW reaction, and their structures were confirmed by spectroscopic techniques and X-ray crystallography.

\section{Acknowledgements}

We would like to thank Aisha Carreto Huilotl for helping during the synthesis process. In the same way, we would like to thank the Mexican Petroleum Institute Project (D. 01495) and the Chemistry Institute (UNAM) for the support provided.

\section{References}

(1) Maase, M.; Massonne, K. In Ionic liquids IIIB: Fundamentals, Progress, Challenges, and 
1

2

3

4

Opportunities; Oxford University Press, 2005; Vol. 902, pp 126-132. doi:10.1021/bk2005-0902.ch010.

(2) Maase, M.; Massonne, K.; Halbritter, K.; Noe, R.; Bartsch, M.; Siegel, W.; Stegmann, V.; Flores, M.; Huttenloch, O.; Becker, M. Method fot the Separation of Acids From Chemical reaction Mixtures by Means of Ionic Fluids. WO/2003/062171, 2003.

(3) Olivier-Bourbigou, H.; Favre, F.; Forestière, A.; Hugues, F. In Green Catalysis; 2010. doi:10.1002/9783527628698.hgc005.

(4) Endter, F. Chemie Ing. Technnik 2004, 30 (5), 305. doi:10.1002/cite.330300506.

(5) Phillips, G. W.; Falling, S. N.; Godleski, S. A.; Monnier, J. R. Continuous process for the manufacture of 2,5-dihydrofurans from $\gamma, \delta$-epoxybutenes. United States patent 5,315,019, 1994.

(6) Koch, P.; Küsters, E. Ionic liquids as solvents in headspace gas chromatography. United States Patent 7,569,149 B2, 2009.

(7) Heffernan, M. L. .; Dennis, R.; Dorsey, J. M.; Foglesong, R. J.; Jones, M. L.; Ogbu, C. O.; Soukri, M.; Spear, K. L.; Orsini, M. A. Preparation of prodrugs of fused heterocyclic inhibitors of D-amino acid. WO2011017634A2, 2011.

(8) Paolo, C.; Vittorino, S.; Villani, F. Preparation, testing and formulation of valproic and valproenoic acid esters as anticonvulsants. EP 250997, 1988.

(9) Korolyov, A.; Dorbes, S.; Azéma, J.; Guidetti, B.; Danel, M.; Lamoral-Theys, D.; Gras, T.; Dubois, J.; Kiss, R.; Martino, R.; Malet-Martino, M. Bioorganic Med. Chem. 2010, 18 (24), 8537. doi:10.1016/j.bmc.2010.10.039.

(10) Rosen, D.; Bloor-Young, D.; Squires, J.; Parkesh, R.; Waters, G.; Vasudevan, S. R.; Lewis, A. M.; Churchill, G. C. Biochem. Biophys. Res. Commun. 2012, 418 (2), 353. 
doi:10.1016/j.bbrc.2012.01.025.

(11) Conway, S. J.; Thuring, J. W.; Andreu, S.; Kvinlaug, B. T.; Roderick, Ll. H.; Bootman, M. D.; Holmes, A. B. Aust. J. Chem. 2006, 59 (12), 887. doi.org/10.1071/CH06357

(12) Nudelman, A.; Rephaeli, A.; Gil-Ad, I.; Abraham, W. Conjugated psychotropic drugs and uses thereof. US Patent 7,939,525 B2, 2011.

(13) Rephaeli, A.; Waks-Yona, S.; Nudelman, A.; Tarasenko, I.; Tarasenko, N.; Phillips, D. R.; Cutts, S. M.; Kessler-Icekson, G. Br. J. Cancer 2007, 96 (11), 1667. doi:10.1038/sj.bjc.6603781.

(14) Rephaeli, A.; Entin-Meer, M.; Angel, D.; Tarasenko, N.; Gruss-Fischer, T.; Bruachman, I.; Phillips, D. R.; Cutts, S. M.; Haas-Kogan, D.; Nudelman, A. Invest. New Drugs 2006, 24 (5), 383. doi:10.1007/s10637-006-6213-1.

(15) Entin-Meer, M.; Rephaeli, A.; Yang, X.; Nudelman, A.; VandenBerg, S. R.; Haas-Kogan, D. A. Mol. Cancer Ther. 2005, 4 (12), 1952. doi:10.1158/1535-7163.

(16) Nudelman, A.; Levovich, I.; Cutts, S. M.; Phillips, D. R.; Rephaeli, A. J. Med. Chem. 2005, 48 (4), 1042. doi:10.1021/jm049428p.

(17) Kensler, D. L.; Kohn, G. K.; Walgenbach, D. D. Compositions for preserving crops and animal feedstuffs. US4123552 A, 1978.

(18) Wu, D.; Qian, X.; Dallas-Pruitt, J. Silicone hydrogel lens with a grafted hydrophilic coating. US 8409599 B2, 2013.

(19) Linhardt, J. G.; Salamone, J. C.; Ammon, D. M.; Hook, D. J. Polymerizable surfactants use as comonomers in forming ophthalmic devices. US 2006/0134169 A1, 2006.

(20) Wang, L.; Deng, Y.; Adeerhamite, O.; Shoukuan, F. Preparation of nano-scale microspheres of magnetic acrylic-based-polymers. CN 1328065 A, 2011. 
1 (21) Kurian, P. V; Joyce, W. H.; Kin-Tai, C. Block copolymers for recovering hydrocarbon

2

3

4 fluids from a subterranean reservoir. US7989401 B2, 2011.

(22) Seher, J.; Viohl, J. Dtsch. Zahnarztl. Z. 1992, 47, 634.

(23) Holmes, M. J.; Klaveness, J.; Rongved, P.; Strande, P. Preparation of acylals and analogs for preparation of biolabile crosslinked ultrasound imaging agents. WO 9217213 A1, 1992.

(24) Goff, D. L.; Yuan, E. L.; Proskow, S. Photopolymerizable polyamide ester resin compositions containing an oxygen scavenger. US4414312 A, 1983.

(25) Okura, H. Thermal-transfer media containing heat-fusible ink. JP 01026494 A, 1989.

(26) Binderup, E.; Hansen, E. T. Synth. Commun. 1984, $14 \quad$ (9), 857. doi:10.1080/00397918408075729.

(27) Horribin, D. F.; Manku, M.; McMordie, A.; Knowles, P.; Redden, P.; Pitt, A. Fatty acid esters as bioactive compounds. WO 1996034855A1, 2001.

(28) Mal, D.; Jana, A.; Ray, S.; Bhattachharya, S.; Patra, A.; De, S. R. Synth. Comminications 2008, 38 (22), 3937. doi:10.1080/00397910802238809.

(29) Schlosser, M.; Limat, D. Tetrahedron 1995, 51 (20), 5807. doi:10.1016/00404020(95)00251-3.

(30) Sydnes, L. K.; Sandberg, M. Tetrahedron 1997, 53 (37), 12679. doi:10.1016/S00404020(97)00789-8.

(31) Schmidt, J.; Schäfer, H. J. Angew. Chemie 1981, 20 (1), 104. doi:10.1002/anie.198101041

(32) Benitez, P.; Delgado, A.; Farrera, J.-A.; Ribó, J. M. Synth. Commun. 1997, 27 (10), 1697. doi:10.1080/00397919708004080. 
1 (33) Kavitake, B. P.; Salunkhe, M.; Wadgaonkar, P. Synth. Commun. 1997, 27 (10), 1703.

2

3

4 doi:10.1080/00397919708004081.

(34) Sukhanov, N. N.; Chetverikov, V. N. Armyanskii Khimicheskii Zhurnal 1987, 40, 323.

(35) Salunkhe, D. G.; Jagdale, M. H.; Salunkhe, M. M.; Wadgaonkar, P. P. Bull. des Sociétés Chim. Belges 1987, 96 (3), 247. doi:10.1002/bscb.19870960311.

(36) Shaw, J. E.; Kunerth, D. C. J. Org. Chem. 1974, 39 (13), 1968. doi:10.1021/jo00927a048.

(37) Holmberg, K.; Hansen, B. Tetrahedron Lett. 1975, 16 (27), 2303.

(38) Klaveness, J.; Strande, P.; Wiggen, U. N. Polymers containing diester units. US5534250 A, 1996.

(39) Likhanova, N.; Lijanova, I.; Morelos-Alvarado, L.; Martínez-García, M.; HernándezOrtega, S.; Olivares-Xometl, O. Curr. Org. Chem. 2013, 17 (1), 79.

(40) Yagi, O.; Shimizu, S. Chem. Lett. 1993, 22 (12), 2041.

(41) R. Martínez-Palou, Química en Microondas.2006, CEM-Publishing, Matthews, N.C., ISBN. 0-9722-2292-1.

(42) Macrae, C. F.; Bruno, I. J.; Chisholm, J. A.; Edgington, P. R.; McCabe, P.; Pidcock, E.; Rodriguez-Monge, L.; Taylor, R.; Van de Streek, J.; Wood, P. . J. Appl. Crystallogr. 2008, 41, 466. doi:10.1107/S0021889807067908.

(43) Takazawa, H.; Ohba, S.; Saito, Y. Acta Crystallogr. Sect. C. Struct. Chem. 1986, 42, 1880. doi:10.1107/S0108270186090182.

(44) Bradley, M. K.; Robinson, J.; Woodruff, D. P. Surf. Sci. 2010, 604 (11-12), 920. doi:10.1016/j.susc.2010.02.021.

(45) Ansari, M. F.; Siddiqui, S. M.; Ahmad, K.; Avecilla, F.; Dharavath, S.; Gourinath, S.; Azam, A. Eur. J. Med. Chem. 2016, 124, 393. doi:10.1016/j.ejmech.2016.08.053. 


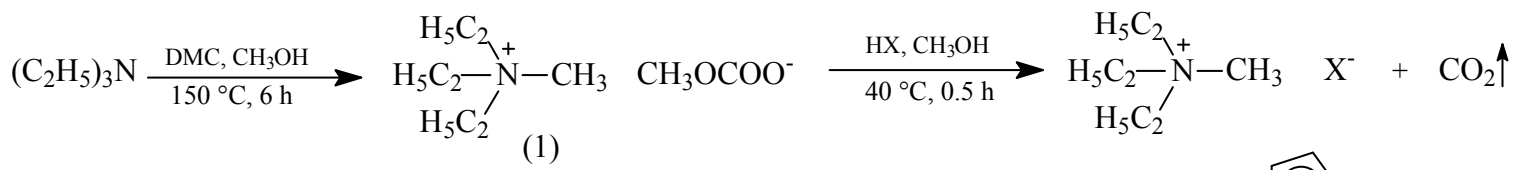

$$
\begin{aligned}
& \mathrm{X}=\mathrm{O}_{\mathrm{COO}} \\
& \mathrm{X}=\widehat{\bigcirc}_{\mathrm{COO}^{-}}^{\mathrm{NH}_{2}} \\
& \mathrm{X}=\mathrm{O}_{\mathrm{N}}-\mathrm{COO}^{-}(2 \mathrm{c})
\end{aligned}
$$

Figure 1. Synthesis scheme of methyltriethylammonium ILs (2a-c). 


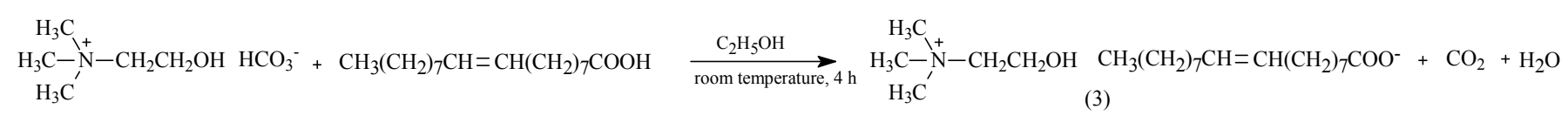

Figure 2. Synthesis scheme of (2-hydroxyethyl)trimethylammonium oleate (3). 


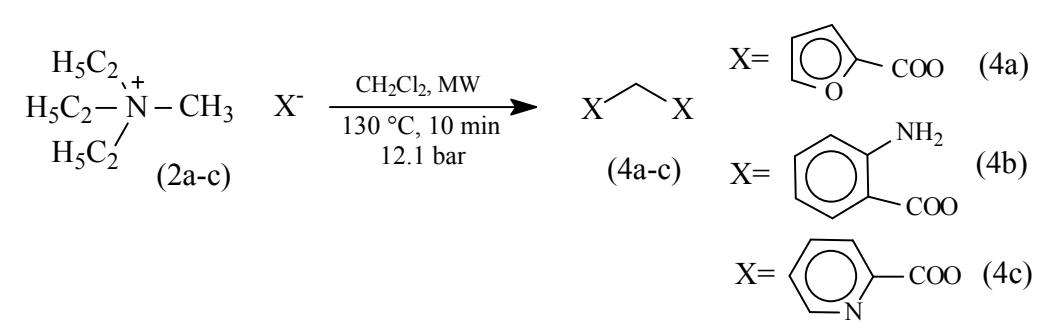

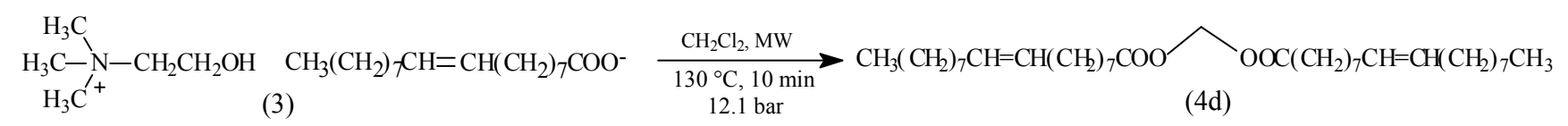

Figure 3. Synthesis scheme of symmetrical MDEs. 


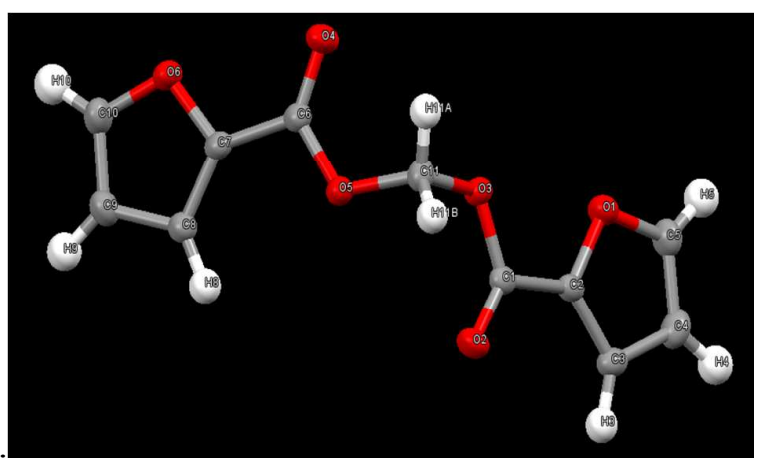

Figure 4. Molecular structure of MDF with atom labels. 


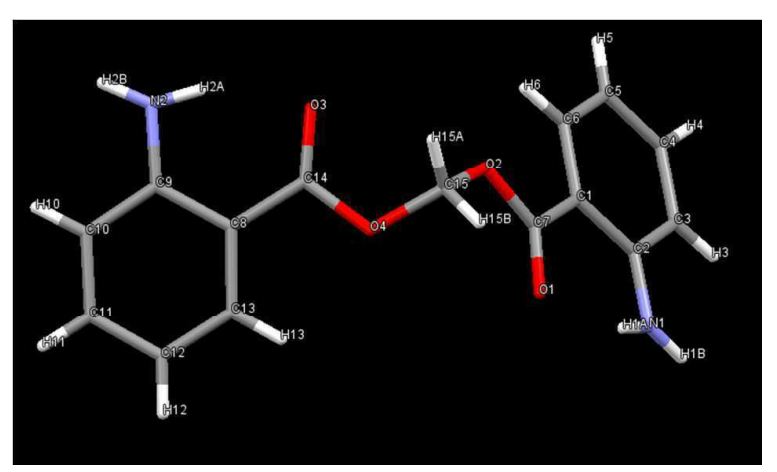

Figure 5. Molecular structure of MDA with atom labels. 


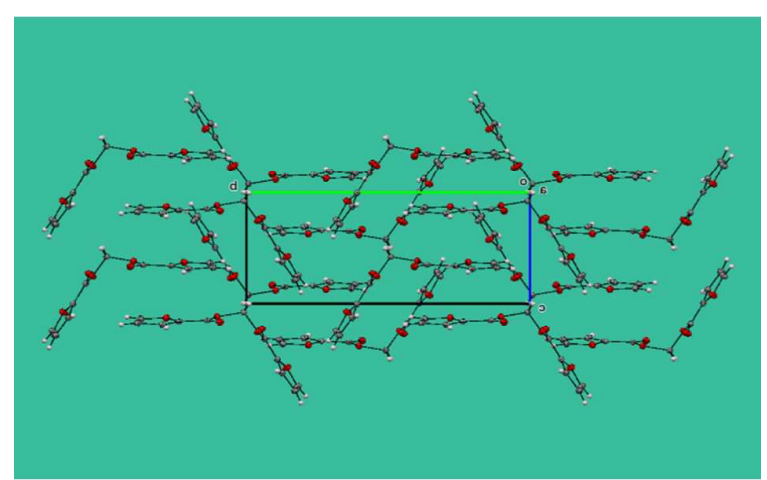

Figure 6. Crystal packing of MDF. 


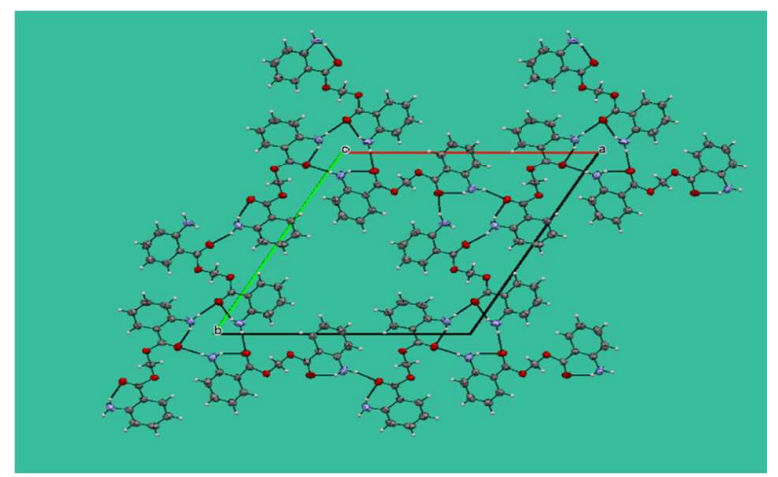

Figure 7. Crystal packing of MDA. 
Table 1. Synthesized compounds.

\begin{tabular}{|c|c|c|c|}
\hline IL & IL Structure & MDE Structure & MDE Name \\
\hline $\begin{array}{c}\text { Methyltriethyl ammonium 2- } \\
\text { furoate (2a) }\end{array}$ & & & Methylene di-2-furoate (4a) \\
\hline $\begin{array}{c}\text { Methyltriethyl ammonium } \\
\text { anthranilate (2b) }\end{array}$ & & & Methylene dianthranilate (4b) \\
\hline $\begin{array}{c}\text { Methyltriethyl ammonium 2- } \\
\text { picolinate }(2 \mathrm{c})\end{array}$ & & & Methylene di-2-picolinate (4c) \\
\hline $\begin{array}{l}\text { (2-Hydroxyethyl) } \\
\text { trimethylammonium oleate (3) }\end{array}$ & $\mathrm{HO}_{\stackrel{+}{\wedge}}^{+} \mathrm{CH}_{3}\left(\mathrm{CH}_{2}\right)_{7} \mathrm{CH}=\mathrm{CH}\left(\mathrm{CH}_{2}\right)_{7} \mathrm{COO}$ & 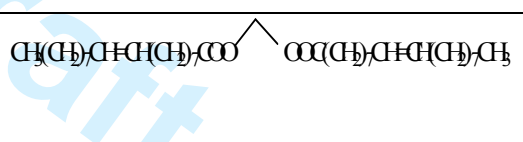 & Methylene dioleate (4d) \\
\hline
\end{tabular}


Structures in the Table 1:<smiles>[Z10]CC(CC)N(CC)CC</smiles><smiles>CCN(CC)CC</smiles><smiles>CCN(CC)CC</smiles>
3

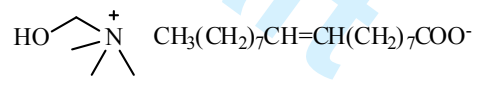

$4 \mathrm{a}$

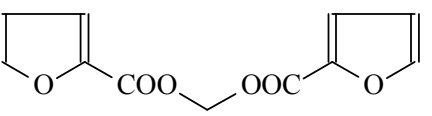

$4 \mathrm{~b}$

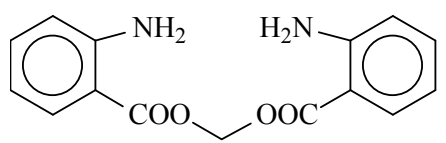

https://mc06.manuscriptcentral.com/cjc-pubs 


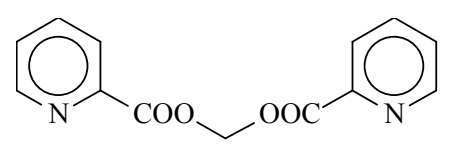

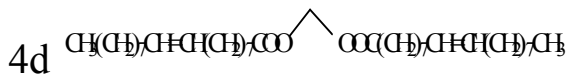


Table 2. Experimental X-ray details.

\begin{tabular}{|c|c|c|}
\hline Crystal data & Methylene di-2-furoate & Methylene dianthranilate \\
\hline Chemical formula & $\mathrm{C}_{11} \mathrm{H}_{8} \mathrm{O}_{6}$ & $\mathrm{C}_{15} \mathrm{H}_{14} \mathrm{~N}_{2} \mathrm{O}_{4}$ \\
\hline MW & 236.17 & 286.28 \\
\hline $\begin{array}{l}\text { Crystal system, space } \\
\text { group }\end{array}$ & Monoclinic, $\mathrm{P} 2_{1} / \mathrm{c}$ & Trigonal, $\mathrm{P} 3_{2}$ \\
\hline Temperature $(\mathrm{k})$ & 150 & 298 \\
\hline Cell angles $\left({ }^{\circ}\right)$ & $\alpha=90, \beta=90.335, \gamma=90$ & $\alpha=90, \beta=90, \gamma=120$ \\
\hline $\begin{array}{l}\text { Unit cell dimensions: a, } \\
\text { b, c }(\AA)\end{array}$ & $9.8738(3), 14.7366(5), 6.9632(2)$ & 17.8996(11), 17.8996(11), 4.1331(3) \\
\hline $\mathrm{V}\left(\AA^{3}\right)$ & $1013.17(5)$ & $1146.81(16)$ \\
\hline $\mathrm{D}_{\mathrm{x}}, \mathrm{g} / \mathrm{cm}^{3}$ & 1.548 & 1.244 \\
\hline $\mathrm{Z}$ & 4 & 3 \\
\hline Radiation type & $\mathrm{MoK} \alpha$ & $\mathrm{CuK} \backslash \alpha$ \\
\hline $\begin{array}{l}\text { Absorption coefficient, } \\
\mu\left(\mathrm{mm}^{-1}\right)\end{array}$ & 0.129 & 0.764 \\
\hline $\begin{array}{l}\text { Crystal size } \\
(\mathrm{mm}) / \text { shape }\end{array}$ & $0.279 \times 0.189 \times 0.157 /$ prism & $0.406 \times 0.036 \times 0.027 /$ needle \\
\hline
\end{tabular}




\begin{tabular}{|c|c|c|}
\hline $\mathrm{T}_{\min }, \mathrm{T}_{\max }$ & $0.965,0.980$ & $0.693,0.754$ \\
\hline Index ranges & $-13 \leq h \leq 13,-20 \leq k \leq 20,-9 \leq l \leq 9$ & $-22 \leq h \leq 22,-22 \leq k \leq 21,-4 \leq l \leq 4$ \\
\hline Reflections collected & 17796 & 29130 \\
\hline Independent reflections & $2709[R($ int $)=0.0319]$ & $3002[R($ int $)=0.0720]$ \\
\hline Measurement device & $\begin{array}{l}\text { Bruker Smart Apex CCD } \\
\text { diffractometer 01-670-01 }\end{array}$ & $\begin{array}{l}\text { Bruker D8 Venture geometry } \\
\text { diffractometer 208039-01 }\end{array}$ \\
\hline $\begin{array}{l}\text { Max. and min. } \\
\text { transmission }\end{array}$ & 0.9803 and 0.9653 & 0.7542 and 0.6926 \\
\hline Refinement method & \multicolumn{2}{|c|}{ Full-matrix least-squares on $F^{2}$} \\
\hline $\begin{array}{l}\text { Data/ restraints/ } \\
\text { parameters }\end{array}$ & $2709 / 0 / 154$ & $3002 / 7 / 202$ \\
\hline Goodness-of-fit on $F^{2}$ & 1.048 & 1.186 \\
\hline $\begin{array}{l}\text { Final } R \text { indices } \\
{[I>2 \operatorname{sigma}(I)]}\end{array}$ & $R 1=0.0392, w R 2=0.0940$ & $R 1=0.0667, w R 2=0.1567$ \\
\hline
\end{tabular}




\begin{tabular}{|l|l|l|}
\hline$R$ indices (all data) & $R 1=0.0494, w R 2=0.1023$ & $R 1=0.1082, w R 2=0.1771$ \\
\hline
\end{tabular}

Computer programs: Data collection: APEX2 v2012.10.0; cell refinement: APEX2 v 2012.10.0; data reduction: 8 SAINT V8.27B; program(s) used to solve structure: SHELXS2012; program(s) used to refine 9 structures: SHELXL2014/7. For the analysis and visualization of the structures, we used the program Mercury $3.8^{42}$. 